\title{
Responses of algae with different life histories to temporal and spatial variability of disturbance in subtidal reefs
}

\author{
Laura Airoldi* \\ Laboratorio di Ecologia Sperimentale, Università di Bologna, 48100 Ravenna, Italy
}

\begin{abstract}
Colonisation of patches disturbed at different times of the year and at different locations was investigated from November 1995 to August 1997 in subtidal, rocky-shore, algal assemblages (Mediterranean Sea, Italy). A field experiment tested specifically: (1) whether and how the success of turf-forming, encrusting and erect algae are influenced by the timing of disturbance and (2) whether recovery of these species is consistent across space (from about $1 \mathrm{~m}$ to 100 s of metres). Clearings were made at 8 different times within 1 year, in order to identify possible temporal trends in responses of algae to disturbance. Reproductive traits of the most abundant algae were also investigated. Encrusting, turf-forming and erect algae responded differently to spatial and temporal variation in disturbance, depending on their varying abilities to colonise available space and on spatial and temporal differences in rates of recruitment and growth. Turf-forming algae colonised space by vegetative propagation and quickly regained spatial dominance in patches cleared at all times of the year and at all locations. Conversely, encrusting and erect species occupied space mostly by colonisation of propagules; their recruitment was influenced by the timing and location of disturbance, probably depending on the concomitant availability of bare rock, viable propagules and favourable environmental conditions. A regime of disturbance adverse to recruitment of erect algae was identified as the probable cause of their low abundance in the study area. Overall, results suggested that while recruitment by sexual propagules can be highly variable through space and time, recovery by vegetative propagation can be constant and highly predictable over a range of environmental conditions, and that vegetative reproduction is likely to be fundamental to spatial dominance in a variety of habitats.
\end{abstract}

KEY WORDS: Disturbance - Patch dynamics - Spatial and temporal scale - Recruitment - Vegetative propagation Polysiphonia setacea Acetabulana acetabulum - Encrusting coralline algae

\section{INTRODUCTION}

Disturbances in natural environments occur over a wide range of spatial and temporal scales (Sousa 1984 a, Pickett \& White 1985), and their frequency and intensity have been shown to exert an important effect on the distribution and dynamics of species (Dayton 1971, Paine \& Levin 1981, Kennelly 1987, Dayton et al. 1992). Many assemblages are commonly affected by disturbance events that are small relative to the area of

\footnotetext{
- Address for correspondence: Corso di Laurea in Scienze Ambientali, Via Tombesi dall'Ova 55, 48100 Ravenna, Italy. E-mail: lairoldi@ambra.unibo.it
}

the habitat (Palumbi \& Jackson 1982, Hawkins \& Hartnoll 1983, Dye 1993, Benedetti-Cecchi \& Cinelli 1994). These disturbances cause the partial or total removal of some organisms within the assemblage, thus generating localised, discrete, gaps of open space (referred to as 'non-isolated' or Type 1 patches, Pickett \& White 1985) that are often colonised soon after they are formed.

Colonisation of disturbed patches is largely controlled by local environmental characteristics, by the time of the year when the assemblage is disturbed and by the life-histories of the individual species (Connell \& Slatyer 1977, Sousa 1980, Hawkins 1981, Keough 1984, Breitburg 1985, Reed 1990, Menge et al. 1993). 
Of particular importance appears to be the different abilities of species to colonise available space by recruitment of sexual propagules or by vegetative propagation. In some marine and terrestrial habitats, for example, it has been suggested that recovery of small patches proceeds mostly by lateral encroachment of neighbouring individuals, while larger patches are mainly colonised by immigration of propagules (Sousa 1979, 1984b, Paine \& Levin 1981, Pickett \& White 1985, Farrell 1989, but see Airoldi 1998). Experimental work has also shown that time of patch formation may have greater effects on colonisation of species that persist by sexual reproduction than on species that colonise space by vegetative propagation (Kim \& DeWreede 1996). Variable responses to disturbance by species with different abilities to colonise space may, therefore, be fundamental in influencing the structure and dynamics of assemblages (Foster 1975, Sousa et al. 1981, McCook 1994, Shumway \& Bertness 1994, Airoldi 1998). Yet, while recruitment of species that secure space by dispersal of propagules has received great attention (for reviews and discussions see Gaines \& Roughgarden 1985, Underwood \& Fairweather 1989, Santelices 1990, Booth \& Brosnan 1995), comparably fewer studies have investigated the role of space occupancy by species via vegetative growth (Abrahamson 1980, Sousa 1980, McCook \& Chapman 1992, 1997)

Subtidal habitats on exposed rocky shores south of Livorno (Ligurian Sea, Italy) are colonised by a dense assemblage consisting mostly of filamentous turf-forming algae, encrusting calcareous algae and a few species of erect algae (Airoldi et al. 1995). Previous observations and experiments have indicated that these algae have different abilities to procure and hold available space (Airoldi 1998, 2000). Turf-forming algae were able to retain space by vegetative propagation, while encrusting and erect algae needed bare rock for settlement of sexual propagules. Moreover, erect algae were outcompeted by turf-forming algae, while encrusting algae were able to grow and dominate primary substrata despite a cover of turf-forming algae. Overall, success of different species was suggested to be potentially related to temporal variability in rates of colonisation following disturbance (Airoldi \& Cinelli 1997. Airoldi 1998). Limited temporal replication of previous experiments, however, did not allow quantitative predictions of colonisation of patches disturbed at different times of the year. The degree of variation was also potentially influenced by the scale of observation (Airoldi \& Virgilio 1998), as the relative abundance of species varied in proximate locations of the shore (Airoldi 1998). Predicting colonisation success of different species needed, therefore, extensive investigations across a range of spatial and temporal scales.
In this study, I investigated variations in spatial and temporal recovery of turf-forming, encrusting and erect algae in discrete patches of bare rock produced at different times of the year and at different locations. A multifactorial field experiment was conducted to test specifically (1) whether and how the overall success of turf-forming, encrusting and erect macroalgae were influenced by the timing of disturbance events and (2) whether patterns of recovery of these species were consistent across a range of spatial scales (from about $1 \mathrm{~m}$ to $100 \mathrm{~s}$ of metres). Experimental clearings were produced at 8 different times over 1 year, in order to identify possible predictable temporal trends in algal responses to disturbance. Reproductive traits and natural fluctuations in cover of the most abundant algae were also investigated to assess whether and how patterns of recovery were related to the life-histories of the different species and to spatial and/or temporally variable availability of propagules. This paper will focus on responses of individual most abundant algae to variable disturbance, while responses at an assemblage level will be presented in a subsequent paper (L.A. unpubl.).

\section{STUDY AREA}

The research was conducted using SCUBA at 3 stations on a wave-exposed rocky reef south of Livorno (Fig. 1A), at depths of 10 to $13 \mathrm{~m}$. Stations were chosen at random and were located 100 s of metres apart (Fig. 1B). At the depths where the study was done, macro-herbivores were virtually absent during most of the year, and disturbance was mainly related to wave action and sediment scour. Previous studies showed that the intensity of these factors varied greatly through time (Airoldi et al. 1996), with maximal disturbance generally occurring in the autumn (mid-September to mid-December), and winter (mid-December to mid-March). Disturbance by sediments and waves generally did not affect the overall cover of turf-forming and encrusting algae (Airoldi \& Virgilio 1998, Airoldi 2000), but violent, episodic, perturbations sometimes produced small, discrete patches of bare rock ranging from $5 \mathrm{~cm}^{2}$ up to about $500 \mathrm{~cm}^{2}$.

At all stations, the bottom consisted of gently sloping sandstone platforms that had eroded to form fields of dense rocky outcrops. On their upper surfaces, the outcrops supported an assemblage dominated by encrusting and turf-forming algae (Airoldi et al. 1995). Encrusting algae mostly consisted of non-geniculate corallines. Also present were some species of Peyssonnelia, usually Peyssonnelia harveyana P. L. et H. M. Crouan ex J. Agardth and Peyssonnelia squamaria (Gmelin) Decaisne. Encrusting algae were covered by 


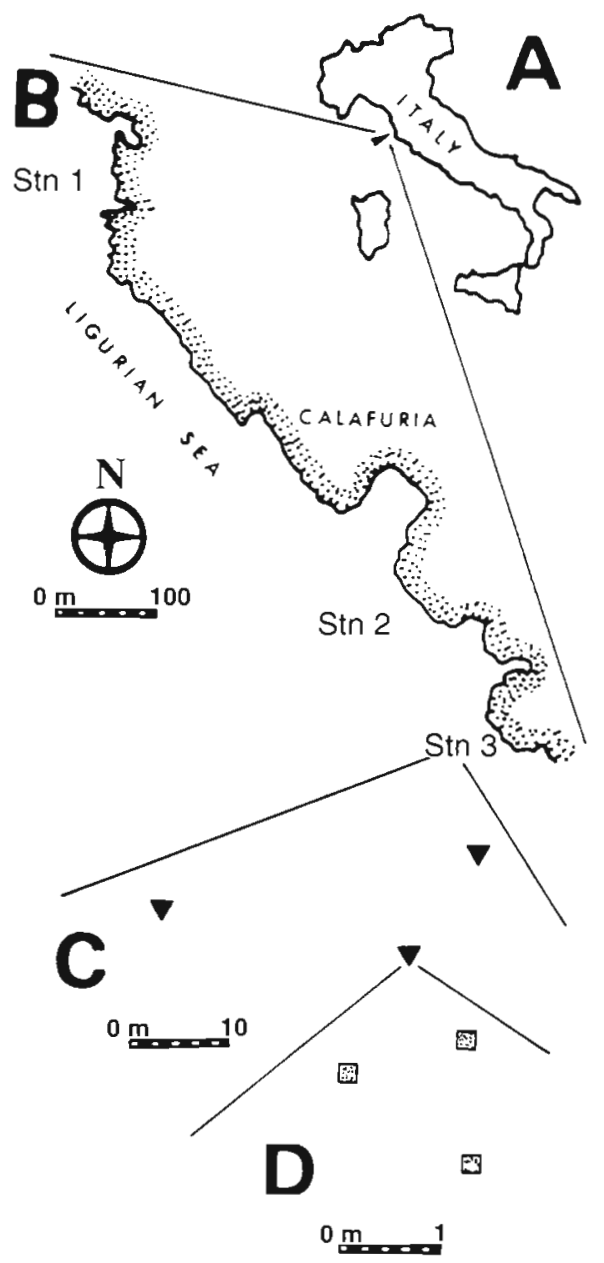

Fig. 1. (A) Location of the study area; (B) location of the 3 stations (Stns 1,2 and 3); (C) example of location of 3 randomly chosen sites within a station; (D) example of location of 3 randomly chosen plots within a site. Symbols for stations, sites and plots are not to scale

a dense filamentous turf up to $1 \mathrm{~cm}$ high, mostly consisting of the species Polysiphonia setacea Hollenberg, which alone generally represented more than $95 \%$ of the total biomass of turf algae (Airoldi et al. 1995; further information about the ecology of $P$. setacea is given in Airoldi 1998). A few erect algae were also present, but they were generally small in size (rarely more than $5 \mathrm{~cm}$ high) and they did not form a canopy. Most of these algae, including Dictyota dichotoma (Hudson) Lamouroux, Padina pavonica (Linnaeus) Lamouroux and Acetabularia acetabulum (Linnaeus) P. C. Silva, were apparent seasonal annuals, which were present as visible macroscopic fronds for a few months during the spring and summer. Conversely, Halimeda tuna (Ellis et Solander) Lamouroux and Flabellia petiolata (Turra) Nizamuddin were persistent as visible macroscopic fronds throughout the year.

\section{METHODS}

Spatial and temporal variability in colonisation of algae following discrete disturbances were investigated by means of a $3 \times 3$ factorial experiment in which patches of bare rock were produced at different times and locations. In the study area, natural patches were generally smaller than $500 \mathrm{~cm}^{2}$ (pers. obs.), and previous experiments with patches ranging from 144 to $400 \mathrm{~cm}^{2}$ showed that patch size was relatively unimportant in influencing recovery of this assemblage compared to timing of disturbance (Airoldi 1998). An intermediate patch size of $225 \mathrm{~cm}^{2}(15 \times 15 \mathrm{~cm})$ was used in this experiment. Patches were cleared of all resident organisms, including encrusting algae, by using a hammer and chisel. The heterogeneity of the substratum, rich in crevices, made scraping sometimes difficult; prostrate axes of algae in the deepest crevices were probably not completely removed, which is similar to the natural situation observed in the area after disturbance (pers. obs.), but the amount of such remnants was always less than $1 \%$ cover. Patches were cleared at 8 randomly chosen times from October 1995 to September 1996 (Table 1). At each time, 3 patches were cleared at each of 3 sites (about $9 \mathrm{~m}^{2}$ ) randomly placed 10 s of metres apart within each of the 3 stations (Fig. 1C,D). Patches were randomly established on the horizontal, top surface of outcrops 1 to $2 \mathrm{~m}$ apart, and permanently marked at their edges with epoxy putty (Subcoat S., Veneziani). Three additional sites, each with 3 unmanipulated $15 \times 15 \mathrm{~cm}$ plots, were established at each station to monitor spatial and temporal variations in abundance of natural algae during the experiment.

Percentage cover of algae in experimental patches was scored at 1 to 3 mo intervals over 1 yr since clearing. A central surface of $10 \times 10 \mathrm{~cm}$ was photographed by using a Nikonos III underwater camera equipped with an electronic flash and a 1:3 extension tube. In the laboratory, slides were projected onto a grid of 100

Table 1. Experimental design used to investigate spatial and temporal variability in colonisation of algae in a subtidal rocky reef

\begin{tabular}{|llcl|}
\hline $\begin{array}{l}\text { Timing of } \\
\text { clearing }\end{array}$ & Stations & Sites & Patches \\
\hline Oct 95 & 1,2 and 3 & 1,2 and 3 & 1,2 and 3 \\
Dec 95 & 1,2 and 3 & 1,2 and 3 & 1,2 and 3 \\
Jan 96 & 1,2 and 3 & 1,2 and 3 & 1,2 and 3 \\
Feb 96 & 1,2 and 3 & 1,2 and 3 & 1,2 and 3 \\
Mar 96 & 1,2 and 3 & 1,2 and 3 & 1,2 and 3 \\
May 96 & 1,2 and 3 & 1,2 and 3 & 1,2 and 3 \\
Jul 96 & 1,2 and 3 & 1,2 and 3 & 1,2 and 3 \\
Sep 96 & 1,2 and 3 & 1,2 and 3 & 1,2 and 3 \\
\hline
\end{tabular}


equally spaced dots, and the percentage cover of each species was expressed as the number of hits, after correction for points which laid over unidentifiable substratum (see Littler \& Littler 1985). Algae present but not scored under grid intercepts (percentage cover $<1 \%$ ) were given an arbitrary cover value of $0.1 \%$. Young specimens of Halimeda tuna and Flabellia petiolata were sometimes difficult to distinguish from photographs. Due to the relative scarcity of $F$. petiolata and to similarity in their life histories (van den Hoek et al. 1995), these 2 species were grouped as 'pluriannuals'. Polysiphonia setacea was by far the dominant turfforming alga, but, as other species were mixed with it (Airoldi et al. 1995), the non-specific category 'turf' was used to designate the thick mat of filamentous species. Similarly, encrusting algae were difficult to identify from photographs and were grouped as 'crusts'.

The effects of timing and location of disturbance on colonisation success of different algae were analysed using 3-way, analyses of variance (ANOVAs), with Timing ( 8 times), Station ( 3 stations) and Site ( 3 sites) as random factors. Timing and Station were orthogonal to each other, while Site was nested in each combination of Timing and Station. Patterns of recruitment of some algae were highly seasonal, showing peaks of abundance during summer months (see 'Results'). Date-bydate comparisons of patches cleared at different times of the year would have confounded differences due to timing of disturbance with either seasonal trends or different ages of patches. Statistical analyses were, therefore, generally run by using as the dependent variable the percentage covers of each species in each plot averaged over sampling dates. This procedure allowed the estimation of the overall effects of location and timing of disturbance on the recruitment success of species, independent of their temporal periodicities. In the case of crusts, analyses were done on percentage covers after 2 to 3 mo from the beginning of each colonisation, as, after that time, recruits of crusts were covered by turf (see 'Results'); thus it was no longer possible to quantify their abundance. In the case of turf, visual inspection of graphs showed that it reached a plateau in all the experimental patches, with values above $70 \%$ cover (see 'Results'). Although restoration of a dense, adult turf takes longer (Airoldi \& Virgilio 1998), recovery to values above $70 \%$ is an important stage in the maintenance of spatial dominance by turf (Airoldi 1998). The effects of timing and location of disturbance on the overall success of turf were, therefore, quantified in terms of differences in colonisation rates rather than in average abundance, and the analysis was run by using the slopes of the regression lines of percentage covers as the dependent variable in individual plots over those months before cover reached values above $70 \%$. Spatial variability of adult, unmanipulated algae was an- alysed by using 2-way ANOVAs, with Station (3 stations) and Site ( 3 sites, nested in Station) as random factors, and with the average percentage cover of each species over sampling dates as the dependent variable. Due to non-independent sampling of individual plots over time, temporal trends were analysed by visual inspection of graphs. Before running ANOVAs, the assumption of homogeneity of variances was examined using Cochran's $C$-test, and angular transformations were used to stabilise variances when necessary. When Timing was found to have a significant effect on colonisation of algae, Ryan's tests were used for a posteriori multiple comparisons of means among plots cleared at different times (Day \& Quinn 1989), in order to identify possible temporal trends in the responses of algae to disturbance.

At each time when patches were cleared, algae removed were collected and sorted in the laboratory, to assess their reproductive status. All erect algae were collected and examined, while for crusts and turf only a random subsample of $5 \times 5 \mathrm{~cm}$ was analysed. Acetabularia acetabulum and crusts were the only conspicuous algae that were found to be fertile (see 'Results'). Reproduction of crusts was detected under a stereomicroscope as presence of conceptacles. Gametangia, carposporangia and sporangia were not separated. Crusts were decalcified using $5 \% \mathrm{HCl}$, and fertile and non-fertile portions of the thallus were divided. The wet biomass of each component was weighed. Fertility was measured as ratio of the biomass of fertile portions over the total biomass of crusts (fertile + non fertile), expressed as a percentage. Spatial and temporal variability in fertility of crusts was analysed with a 3-way ANOVA, with Time ( 8 times), Station ( 3 stations) and Site ( 3 sites, nested in each combination of Times and Station) as random factors. The relationship between early recruitment of crusts and fertility of within-site adult crusts at the time when patches were cleared was measured with a linear correlation between the average fertility of crusts at each site and time and the average cover of crusts at each site after 2 to 3 mo from. the beginning of each colonisation.

\section{RESULTS}

\section{Spatial and temporal patterns of unmanipulated algae}

Crusts were abundant on primary substrata, but due to overgrowth by turf they could not be quantified by photographic sampling. Turf and pluriannuals were persistent during the study, although their cover fluctuated over time (Fig. 2). Cover of turf was generally greater than $70 \%$, reaching maximal values during 


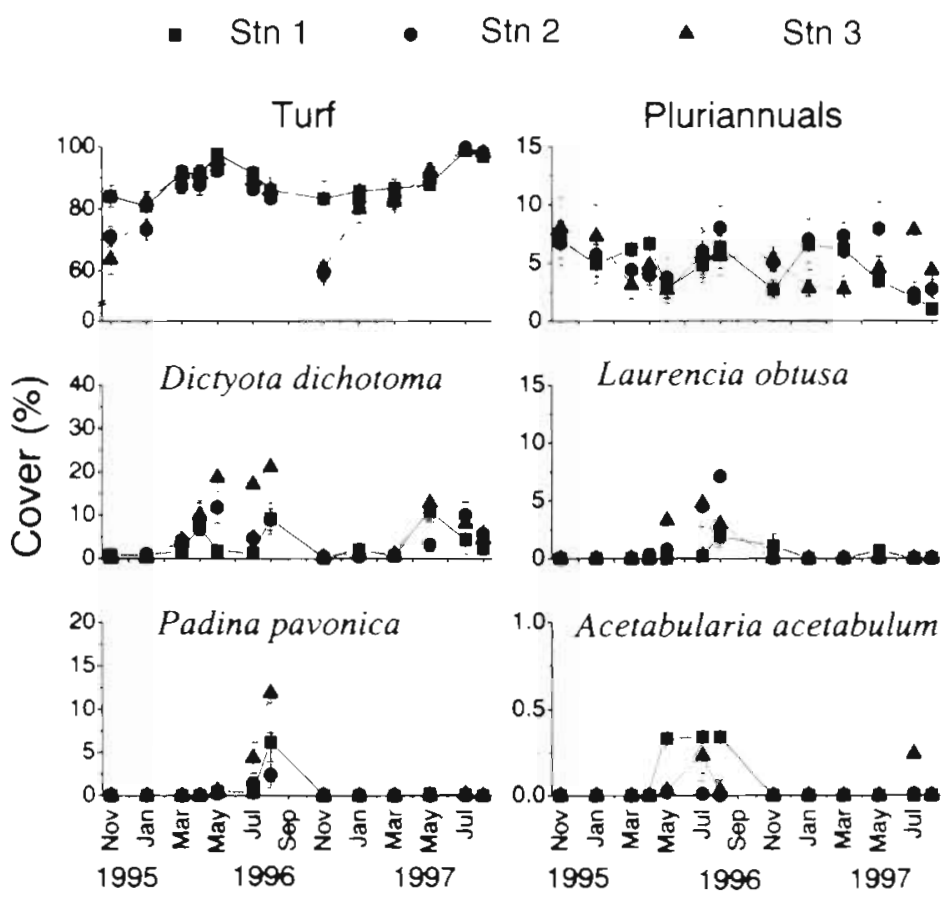

Fig. 2. Temporal variations of most abundant macroalgae in subtidal rocky reefs South of Livorno. Data are mean percentage covers $( \pm \mathrm{SE}, \mathrm{n}=9)$ at 3 stations (Stns 1 to 3 ) from November 1995 to August 1997. Data were pooled across 3 sites within each station

spring and summer months at all stations. Cover of phuriannuals fluctuated between 1 and $8 \%$, but no clear temporal trends were observed (Fig. 2). Abun- dance of apparent seasonal erect algae was low during most of the year. Dictyota dichotoma, Laurencia obtusa (Linnaeus) Lamouroux, Padina pavonica and Acetabularia acetabulum were present in the area as macroscopic detectable stages only for a few months during spring and summer (Fig. 2). Only a few other erect species were observed, including Wrangelia penicillata (C. Agardh) C. Agardh and Tricleocarpa fragilis (Linnaeus) Huisman et Towsend, but these occurred too sporadically for meaningful analyses.

Cover of turf was similar among sites, while significant differences were detected among stations (Table 2). Differences among stations occurred mostly during November 1996 (Fig. 2). Covers of pluriannuals and Dictyota dichotoma varied significantly among sites, while no differences were observed in the overall abundance of these species among stations. Abundance of other species varied greatly among nearby patches within sites, as suggested by large standard errors (Fig. 2), possibly masking patterns at larger spatial scales.

\section{Reproductive traits}

Acetabularia acetabulum and crusts were the only common algae that were found to be fertile. A. acetabulum first occurred as a macroscopic visible stage in May (Fig. 2), when it appeared as elongated sterile

Table 2. ANOVAs of covers of dominant macroalgae at different stations and sites. Factors: Station ( 3 stations, random) and Site ( 3 sites, random, nested in Station). Analyses were run using the covers (\%) of each alga in each plot averaged over sampling dates as the dependent variable. ns = non-significant, $" \mathrm{p}<0.05, \cdots p<0.01$

\begin{tabular}{|c|c|c|c|c|c|}
\hline & Source of variation & $\mathrm{df}$ & MS & $F$ & $\begin{array}{l}\text { Cochran's } C \text {-test } \\
\text { (transformation) }\end{array}$ \\
\hline Turf & $\begin{array}{l}\text { Station } \\
\text { Site } \\
\text { Residual }\end{array}$ & $\begin{array}{r}2 \\
6 \\
18\end{array}$ & $\begin{array}{r}67.29 \\
10.66 \\
9.45\end{array}$ & $\begin{array}{l}6.31^{\circ} \\
1.12 \mathrm{~ns}\end{array}$ & $\begin{array}{c}C=0.46 \mathrm{~ns} \\
(\text { None })\end{array}$ \\
\hline Pluriannuals & $\begin{array}{l}\text { Station } \\
\text { Site } \\
\text { Residual }\end{array}$ & $\begin{array}{r}2 \\
6 \\
18\end{array}$ & $\begin{array}{r}1.40 \\
12.65 \\
2.08\end{array}$ & $\begin{array}{l}0.11 \mathrm{~ns} \\
6.06^{\cdots}\end{array}$ & $\begin{array}{c}C=0.41 \mathrm{~ns} \\
\text { (None) }\end{array}$ \\
\hline Dictyota dichotoma & $\begin{array}{l}\text { Station } \\
\text { Site } \\
\text { Residual }\end{array}$ & $\begin{array}{r}2 \\
6 \\
18\end{array}$ & $\begin{array}{r}42.27 \\
48.11 \\
8.76\end{array}$ & $\begin{array}{l}0.88 \mathrm{~ns} \\
5.49^{\cdots}\end{array}$ & $\begin{array}{c}C=0.44 \mathrm{~ns} \\
(\text { None })\end{array}$ \\
\hline Laurencia obtusa & $\begin{array}{l}\text { Station } \\
\text { Site } \\
\text { Residual }\end{array}$ & $\begin{array}{r}2 \\
6 \\
18\end{array}$ & $\begin{array}{l}1.13 \\
2.66 \\
1.01\end{array}$ & $\begin{array}{l}0.43 \mathrm{~ns} \\
2.63 \mathrm{~ns}\end{array}$ & $\begin{array}{c}C=0.47 \mathrm{~ns} \\
\text { (None) }\end{array}$ \\
\hline Padina pavonica & $\begin{array}{l}\text { Station } \\
\text { Site } \\
\text { Residual }\end{array}$ & $\begin{array}{r}2 \\
6 \\
18\end{array}$ & $\begin{array}{l}2.46 \\
1.31 \\
0.77\end{array}$ & $\begin{array}{l}1.88 \mathrm{~ns} \\
1.69 \mathrm{~ns}\end{array}$ & $\begin{array}{c}C=0.37 \mathrm{~ns} \\
\text { (None) }\end{array}$ \\
\hline Acetabularia acetabulum & $\begin{array}{l}\text { Station } \\
\text { Site } \\
\text { Residual }\end{array}$ & $\begin{array}{r}2 \\
6 \\
18\end{array}$ & $\begin{array}{l}0.01 \\
0.01 \\
0.01\end{array}$ & $\begin{array}{l}0.98 \mathrm{~ns} \\
1.21 \mathrm{~ns}\end{array}$ & $\begin{array}{c}C=0.87 \cdot \\
\text { (None) }\end{array}$ \\
\hline
\end{tabular}




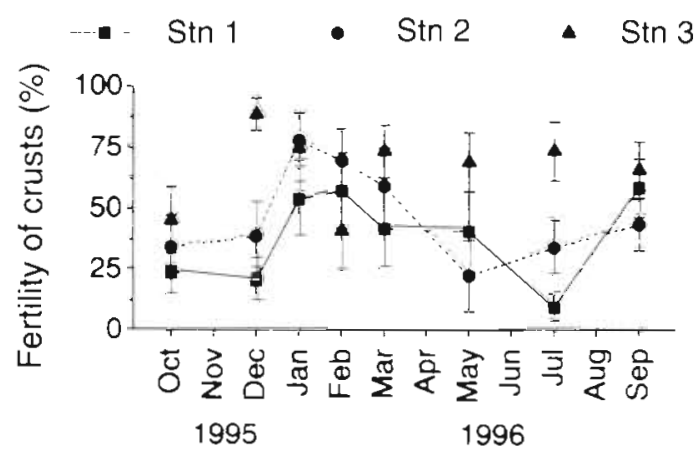

Fig. 3. Fertility of crusts from October 1995 to September 1996 at 3 stations (Stns 1 to 3 ). Data are means $( \pm \mathrm{SE}, \mathrm{n}=9$ ) pooled across 3 sites within each station. Fertility was quantified as the ratio of the biomass of fertile portions over the total biomass of crusts (fertile + non fertile), expressed as \%

stalks. Within 1 to $2 \mathrm{mo}$, these developed reproductive cups, consisting of whorls of gametangial rays. Release of gametes by gametangial cysts generally occurs shortly before cups become senescent (Bonotto 1994), which happened towards the end of the summer at all stations

Crusts were reproductive throughout the year. Fertility fluctuated over time (Fig. 3), but these differences were not significant (Time: $F_{7.48}=1.4, p>0.05$; Time $\times$ Station: $\left.F_{14,48}=1.38, p>0.05\right)$. Fertility was similar across nearby sites (Site [Time $\times$ Station]: $F_{48,144}=1.27, \mathrm{p}>0.05$ ) whereas significant differences were observed among stations (Station: $F_{2,48}=6.69, \mathrm{p}<0.01$ ), with higher values at Stn 3 compared to Stns 1 and 2 (Fig. 3).

No sexual reproductive structures were recorded for the turf-forming alga Polysiphonia setacea. So far, vegetative propagation is the only form of reproduction that has been observed both in the field and in culture for specimens of this species from various areas of the Mediterranean (Airoldi 1998 and references therein, Rindi et al. 1999). No reproductive structures were detected for any of the other species, for which sexual reproduction is known to commonly occur throughout the time period that they are present as visible stages. Fertile specimens (gametangia) of Halimeda tuna were observed in the field in August and September. Only sterile individuals were, however, present in the samples collected.

\section{Effects of timing and location of disturbance}

\section{Crusts}

Crusts were always among the first colonisers of bare rock, reaching up to $68 \%$ cover in 2 mo (Fig. 4). After that time, recruits of crusts became largely covered by turf, which made it difficult to

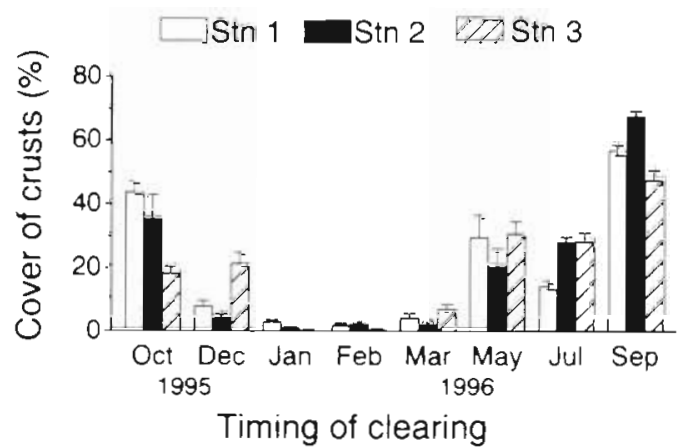

Fig. 4. Recruitment of crusts in patches of bare rock cleared at 3 stations (Stns 1 to 3 ) and at 8 different times (October 1995 to September 1996). Data are mean percentage covers (+SE, $\mathrm{n}=9$ ) measured after 2 to 3 mo since patches were cleared. Data are pooled across 3 sites within each station

quantify their growth over a longer time. Crusts colonised space mostly by recruitment of propagules and subsequent vegetative growth, but lateral invasion by surrounding specimens was also occasionally observed. Early recruitment of crusts was highly variable in time and space (Table 3). Recruitment was generally less in patches cleared from December 1995 to March 1996 (Fig. 4), but responses of crusts to timing of disturbance differed across stations, as indicated by the significant Timing $\times$ Station interaction and by Ryan's tests (Table 3). Recruitment of crusts also differed significantly among sites within stations (Table 3). This spatial and temporal variability was not related to differences in fertility of within-site adult crusts at the times when patches were cleared (linear correlation: $r^{2}=0.01, p>0.05$ ).

\section{Turf}

Visual inspection of plots showed that turf colonised bare space mostly by lateral encroachment from the periphery and regrowth of surviving prostrate axes. Recovery of turf was always quick, generally following an S-shaped curve (Fig. 5). After an initial exponential growth phase, turf reached a plateau in a few months with values of about 70 to $100 \%$ cover. Rates of recovery of turf significantly differed among patches cleared at different times and locations (Table 3). Recovery was generally quicker in patches cleared in December 1995 and January 1996 (Fig. 5), but this pattern was significant only at Stn 2 (Ryan's test, Table 3). Recovery of turf also differed significantly among sites within stations (Table 3). Initial differences in rates of recovery, however, decreased over time, and after 1 yr the percentage cover of turf was similar at all stations, independent of the original timing of clearing (Fig. 5). 
Table 3. ANOVAs of effects of timing and location of disturbance on colonisation success of dominant macroalgae. Factors: Timing ( 8 times, random), Station ( 3 stations, random) and Site ( 3 sites, random, nested in Timing $\times$ Station). Dependent variables: for Crusts, the covers (\%) after 2 to 3 mo from the beginning of colonisation; for Turf, the slopes of the regression lines of covers (\%) in each plot over those months before cover reached values above $70 \%$; for all other species, the covers (\%) in each plot averaged over sampling dates (for more information see 'Methods'). ns = non-significant, ${ }^{\circ} p<0.05,{ }^{\prime} p<0.01 \cdots p<0.001$

\begin{tabular}{|c|c|c|c|c|c|}
\hline $\begin{array}{l}\text { Source of } \\
\text { variation }\end{array}$ & df & MS & $F$ & $\begin{array}{l}\text { Cochran's C-test } \\
\text { (transformation) }\end{array}$ & Ryan's test \\
\hline \multicolumn{6}{|l|}{ Crusts } \\
\hline Timing $=\mathrm{T}$ & 7 & 1.927 & $19.96 \cdots$ & \multirow{5}{*}{$\begin{array}{c}C=0.107 \mathrm{~ns} \\
\text { (Angular) }\end{array}$} & \\
\hline Station $=\mathrm{S}$ & 2 & 0.001 & $0.01 \mathrm{~ns}$ & & Stn 1. Sep $=$ Oct $>$ May $>$ Jul $=$ Dec $=$ Mar $=\mathrm{Jan}=$ Feb \\
\hline$T \times S$ & 14 & 0.097 & $3.87 \cdots$ & & Stn 2: Sep $>$ Oct $=\mathrm{Jul}=\mathrm{May}>\mathrm{Dec}=\mathrm{Mar}=\mathrm{Feb}=\mathrm{Jan}$ \\
\hline Site $(T \times S)$ & 48 & 0.025 & $2.58 \cdots$ & & Stn 3: Sep $>$ May $=$ Jul $=$ Dec $=$ Oct $>$ Mar $=$ Feb $=\mathrm{Jan}$ \\
\hline Residual & 144 & 0.009 & & & \\
\hline \multicolumn{6}{|l|}{ Turf } \\
\hline Timing $=\mathrm{T}$ & 7 & 351.9 & $6.73^{*}$ & \multirow{5}{*}{$\begin{array}{c}C=0.069 \mathrm{~ns} \\
(\text { None })\end{array}$} & \\
\hline Station $=\mathrm{S}$ & 2 & 257.4 & $4.92^{*}$ & & $\operatorname{Stn} 1: \mathrm{Jan}=\mathrm{Dec}=\mathrm{Mar}=\mathrm{Jul}=\mathrm{Oct}=\mathrm{May}=\mathrm{Sep}=\mathrm{Feb}$ \\
\hline $\mathrm{T} \times \mathrm{S}$ & 14 & 52.3 & $2.21^{*}$ & & $\operatorname{Stn} 2: \mathrm{Jan}=\mathrm{Dec}>\mathrm{Oct}=\mathrm{Mar}=\mathrm{Jul}=\mathrm{May}=\mathrm{Sep}=\mathrm{Feb}$ \\
\hline Site $(T \times S)$ & 48 & 23.7 & $2.24 \cdots$ & & Stn 3: Jan $=$ Mar $=$ Jul $=$ May $=$ Dec $=$ Oct $=$ Sep $=$ Feb \\
\hline Residual & 144 & 10.5 & & & \\
\hline \multicolumn{6}{|l|}{ Pluriannuals } \\
\hline Timing $=\mathrm{T}$ & 7 & 5.97 & $1.93 \mathrm{~ns}$ & \multirow{5}{*}{$\begin{array}{c}C=0.078 \mathrm{~ns} \\
\text { (None) }\end{array}$} & \\
\hline Station $=\mathrm{S}$ & 2 & 0.67 & $0.22 \mathrm{~ns}$ & & \\
\hline $\mathrm{T} \times \mathrm{S}$ & 14 & 3.09 & $1.66 \mathrm{~ns}$ & & \\
\hline Site $(T \times S)$ & 48 & 1.86 & $3.14 \cdots$ & & \\
\hline Residual & 144 & 0.59 & & & \\
\hline \multicolumn{6}{|l|}{ Dictyota dichotoma } \\
\hline Timing $=\mathrm{T}$ & 7 & 141.1 & $3.17^{\circ}$ & \multirow{5}{*}{$\begin{array}{l}C=0.113 \mathrm{~ns} \\
\text { (None) }\end{array}$} & \\
\hline Station $=\mathrm{S}$ & 2 & 11.5 & $0.26 \mathrm{~ns}$ & & Stn 1: Mar $=$ May $>$ Sep $=$ Feb $=\mathrm{Jan}=\mathrm{Jul}=\mathrm{Oct}=\mathrm{Dec}$ \\
\hline $\mathrm{T} \times \mathrm{S}$ & 14 & 44.5 & $2.88 \cdots$ & & Stn 2: May $=$ Sep $=$ Jul $=$ Mar $=\mathrm{Oct}=\mathrm{Feb}=\mathrm{Dec}=\mathrm{Jan}$ \\
\hline Site $(T \times S)$ & 48 & 15.5 & $1.59^{\circ}$ & & Stn 3: May $=$ Feb $>$ Jan $=$ Sep $=$ Mar $=\mathrm{Jul}=\mathrm{Dec}=$ Oct \\
\hline Residual & 144 & 9.7 & & & \\
\hline \multicolumn{6}{|l|}{ Laurencia obtusa } \\
\hline Timing $=T$ & 7 & 37.1 & $0.64 \mathrm{~ns}$ & \multirow{5}{*}{$\begin{array}{c}C=0.093 \mathrm{~ns} \\
\text { (Angular) }\end{array}$} & \\
\hline Station $=S$ & 2 & 43.1 & $0.75 \mathrm{~ns}$ & & $\operatorname{Stn} 1: \mathrm{Sep}=\mathrm{Oct}=\mathrm{Jul}=\mathrm{Mar}=\mathrm{Dec}=\mathrm{May}=\mathrm{Feb}=\mathrm{Jan}$ \\
\hline $\mathrm{T} \times \mathrm{S}$ & 14 & 57.8 & $4.73 \cdots$ & & Stn 2: Mar $=$ May $=$ Feb $=$ Dec $=\mathrm{Jan}=\mathrm{Oct}=\mathrm{Jul}=\mathrm{Sep}$ \\
\hline Site $(T \times S)$ & 48 & 12.2 & $2.27 \cdots$ & & Stn 3: Oct $>$ May $=$ Mar $=\mathrm{Dec}=\mathrm{Feb}=\mathrm{Jan}=\mathrm{Jul}=\mathrm{Sep}$ \\
\hline Residual & 144 & 5.4 & & & \\
\hline \multicolumn{6}{|l|}{ Padina pavonica } \\
\hline Timing $=\mathrm{T}$ & 7 & 119.5 & $4.25^{\circ}$ & \multirow{5}{*}{$\begin{array}{c}C=0.107 \mathrm{~ns} \\
\text { (Angular) }\end{array}$} & \multirow{5}{*}{$\mathrm{Jul}>\mathrm{Sep}=\mathrm{Oct}=\mathrm{Mar}=\mathrm{Dec}=\mathrm{May}=\mathrm{Feb}=\mathrm{Jan}$} \\
\hline Station $=\mathrm{S}$ & 2 & 149.9 & $5.33^{\bullet}$ & & \\
\hline $\mathrm{T} \times \mathrm{S}$ & 14 & 28.1 & $1.41 \mathrm{~ns}$ & & \\
\hline Site $(T \times S)$ & 48 & 19.9 & $1.35 \mathrm{~ns}$ & & \\
\hline Residual & 144 & 14.7 & & & \\
\hline \multicolumn{6}{|c|}{ Acetabularia acetabulum } \\
\hline Timing $=\mathrm{T}$ & 7 & 419.0 & $9.82 \cdots$ & \multirow{5}{*}{$\begin{array}{c}C=0.096 \mathrm{~ns} \\
\text { (Angular) }\end{array}$} & \\
\hline Station $=S$ & 2 & 85.5 & $2.01 \mathrm{~ns}$ & & Stn 1: Sep $>$ Oct $=\mathrm{Jul}=\mathrm{Jan}=\mathrm{Dec}=\mathrm{May}=\mathrm{Mar}=\mathrm{Feb}$ \\
\hline $\mathrm{T} \times \mathrm{S}$ & 14 & 42.6 & $2.76^{\cdots}$ & & Stn 2: Oct $=$ Sep $>$ Jul $=$ Feb $=\operatorname{Jan}=\operatorname{Mar}=$ May $=$ Dec \\
\hline Site $(T \times S)$ & 48 & 15.4 & $2.21 \cdots$ & & Stn 3: Oct $=\operatorname{Sep}>$ Dec $=\mathrm{Jul}==\mathrm{May}=\mathrm{Mar}=\mathrm{Jan}=\mathrm{Feb}$ \\
\hline Residual & 144 & 7.0 & & & \\
\hline
\end{tabular}

\section{Erect algae}

All erect algae colonised patches of bare rock by immigration of propagules. Colonisation of pluriannuals showed an increasing trend over time (Fig. 6). This pattern generally reflected an increase in size of firstly settled individuals rather than an increase in number of new recruits. Pluriannuals were not affected by timing or by location of disturbance (Table 3), as colonisation rates were similar among patches cleared at different times and stations (Fig. 6). Conversely, colonisation of pluriannuals differed among patches in nearby sites (Table 3). Patterns of recruitment of other erect algae were highly variable over time, showing peaks of abundance during summer months. Timing of clearing significantly influenced their recruitment success, although its effects generally varied depending on the species and location of patches, resulting in significant Timing $\times$ Station effects for all species except Padina pavonica (Table 3). Recruitment of apparent seasonal 


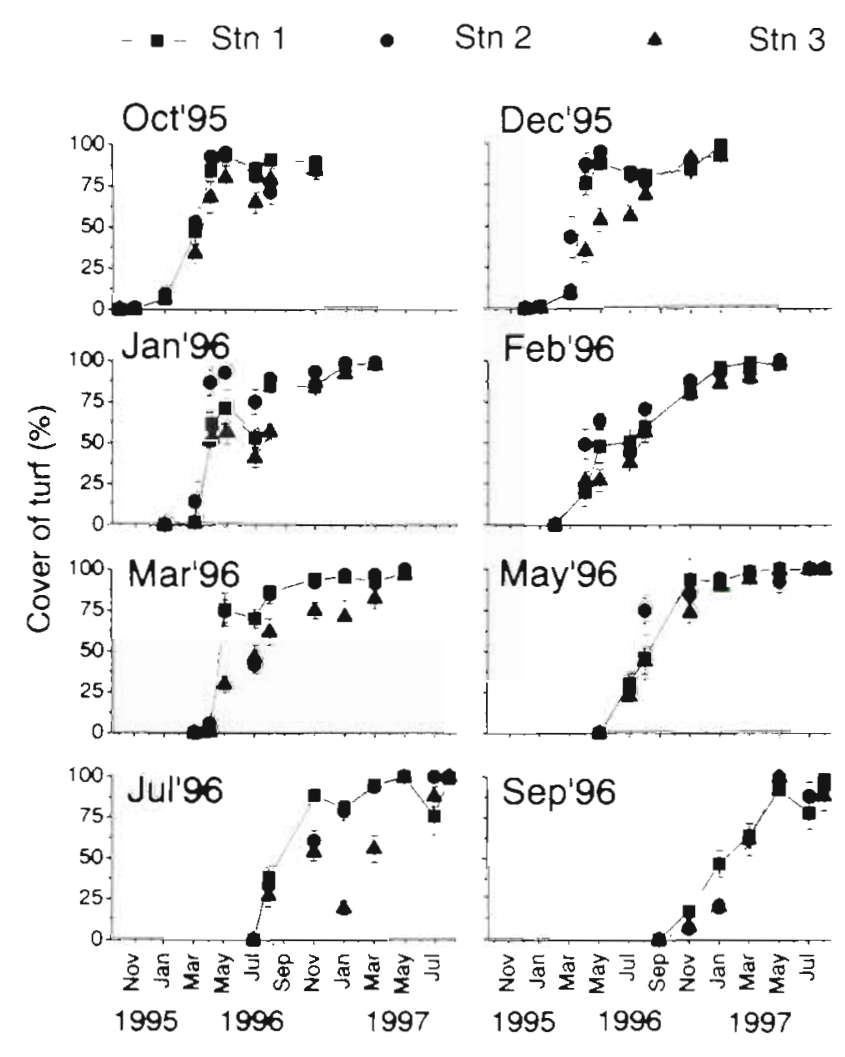

Fig. 5. Cover of algal turf in patches of bare rock cleared at 8 different times (October 1995 to September 1996) and at 3 different stations (Stns 1 to 3 ). Data are mean percentage covers $( \pm \mathrm{SE}, \mathrm{n}=9$ ) over 1 yr since patches were cleared. Data are pooled across 3 sites within each station

algae was also generally variable among sites within stations (Table 3 ). For the sake of brevity, only graphs relative to Dictyota dichotoma and Acetabularia acetabulum are shown (Figs. $7 \&$ 8). Recruitment of D. dichotoma was generally greater in patches cleared during February to May 1996 (Fig. 7), but patterns were significant only at Stns 1 and 3 (Ryan's test, Table 3). A. acetabulum (Fig. 8) and P. pavonica recruited almost exclusively in patches cleared in September and October 1996 and in July 1996, respectively, and such patterns were generally consistent among stations (Ryan's tests, Table 3). Laurencia obtusa recruited in patches cleared at all times of the year. Its overall abundance was generally greater in patches cleared in spring and autumn months, but such differences were generally not statistically significant (Ryan's test, Table 3).

\section{DISCUSSION}

Crusts, turf and erect algae responded differently to spatial and temporal variation in disturbance. Such variable patterns appeared to be related to their differ-
- $\operatorname{Stn} 1 \quad \operatorname{Stn} 2$ - $\operatorname{Stn} 3$
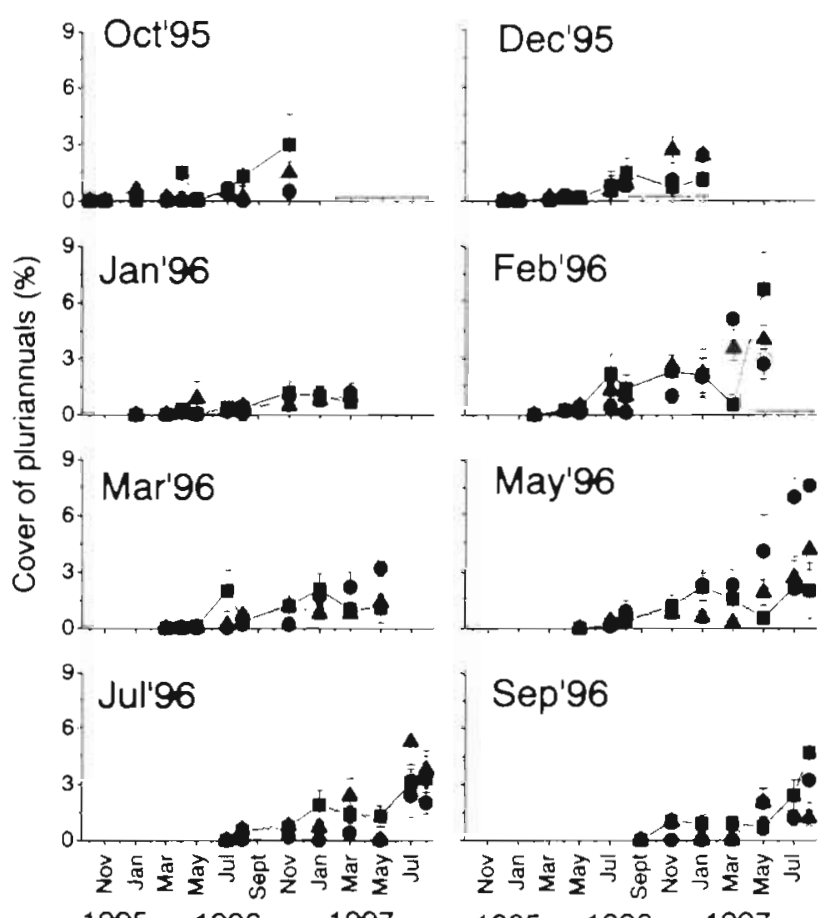

Sep'96 1995

1997

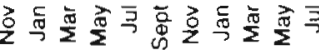

19951996

1997

Fig. 6. Cover of pluriannual algae in patches of bare rock cleared at 8 different times (October 1995 to September 1996) and at 3 different stations (Stns 1 to 3). Data are mean percentage covers $( \pm S E, n=9)$ over 1 yr since patches were cleared. Data are pooled across 3 sites within each station

ent abilities to colonise available space and to spatial and temporal differences in rates of recruitment and growth. Algal turf, which occupied space by vegetative propagation, was able to quickly regain spatial dominance in patches cleared at all times of the year and at all locations, despite significant differences in rates of recovery. Conversely, recruitment of crusts and erect species, which occupied space mostly by dispersal of sexual propagules, was influenced by the timing and location of disturbance, probably depending on the concomitant availability of bare rock, propagules and favourable environmental conditions.

In many marine habitats, including the study area, severe disturbances are rare, and often tend to occur at certain times of the year. Examples of periodic, predictable disturbances include storms, sand inundations, desiccation, changes in water chemistry and human-related perturbations (Dayton 1971, Littler et al. 1983, Witman 1987, Breitburg 1992, Williams 1994, Airoldi et al. 1996, Keough \& Quinn 1998). The results of this study clearly indicate that temporal variability of disturbance may significantly affect the colonisation and persistence of algae that recruit by propagules. Some erect 


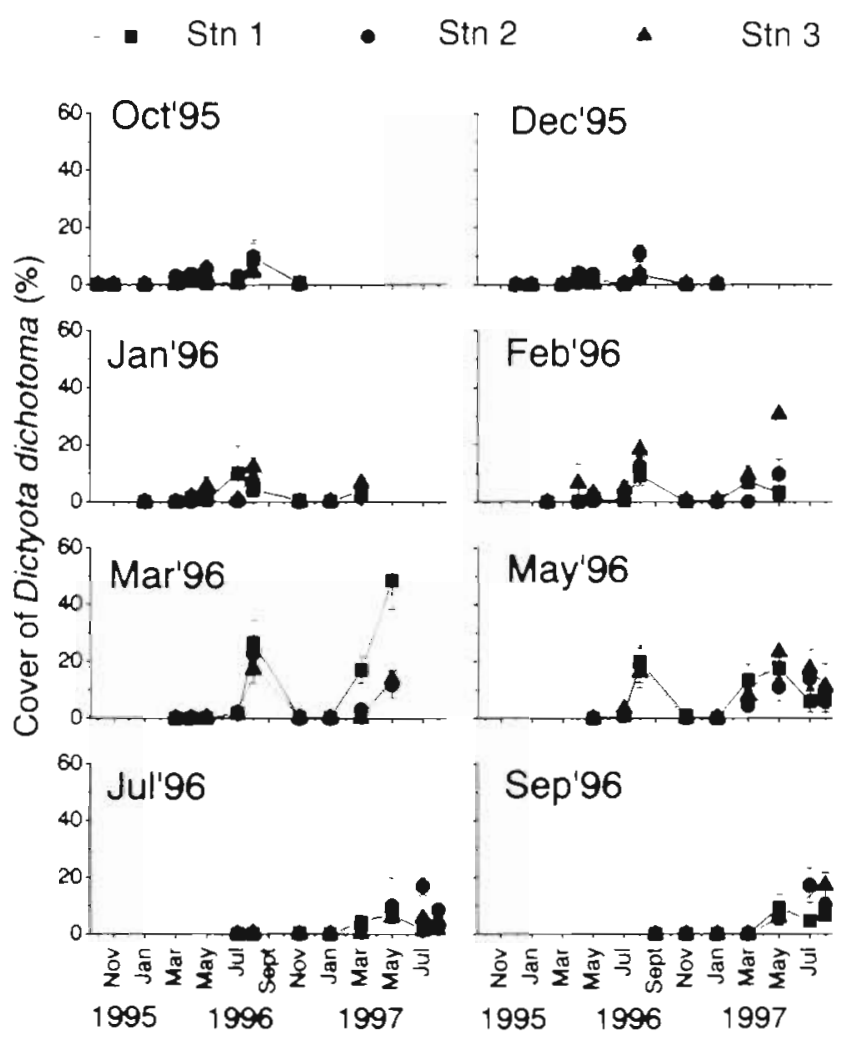

Fig. 7. Cover of Dictyota dichotoma in patches of bare rock cleared at 8 different times (October 1995 to September 1996) and at 3 different stations (Stns 1 to 3 ). Data are mean percentage covers $( \pm S E, n=9$ ) over 1 yr since patches were cleared. Data are pooled across 3 sites within each station

algae, like Acetabularia acetabulum and Padina pavonica, had restricted colonisation 'windows' (sensu Reed et al. 1988, Menge et al. 1993), only recruiting in patches cleared during late-summer and early-autumn months. Dictyota dichotoma and Laurencia obtusa, conversely, colonised bare rock throughout the year, although their abundances were generally greater in patches cleared in spring to early autumn months.

This temporal variability in the responses of algae to disturbance suggests that it might be possible to predict yearly patterns of abundance of some species from annual variations in the timing of disturbance (see also Turner 1983). For Dictyota dichotoma this hypothesis was supported by consistency of results of this study with results of previous experiments on the same assemblage (Airoldi \& Cinelli 1997, Airoldi 1998). In such experiments, when patches of bare rock were cleared in June and December 1992 and 1994, respectively, recruitment of $D$. dichotoma was always significantly greater in patches cleared in June than in those cleared in December, as also observed in this study. Responses of Padina pavonica and Acetabularia acetabulum to variable timing of disturbance, how-

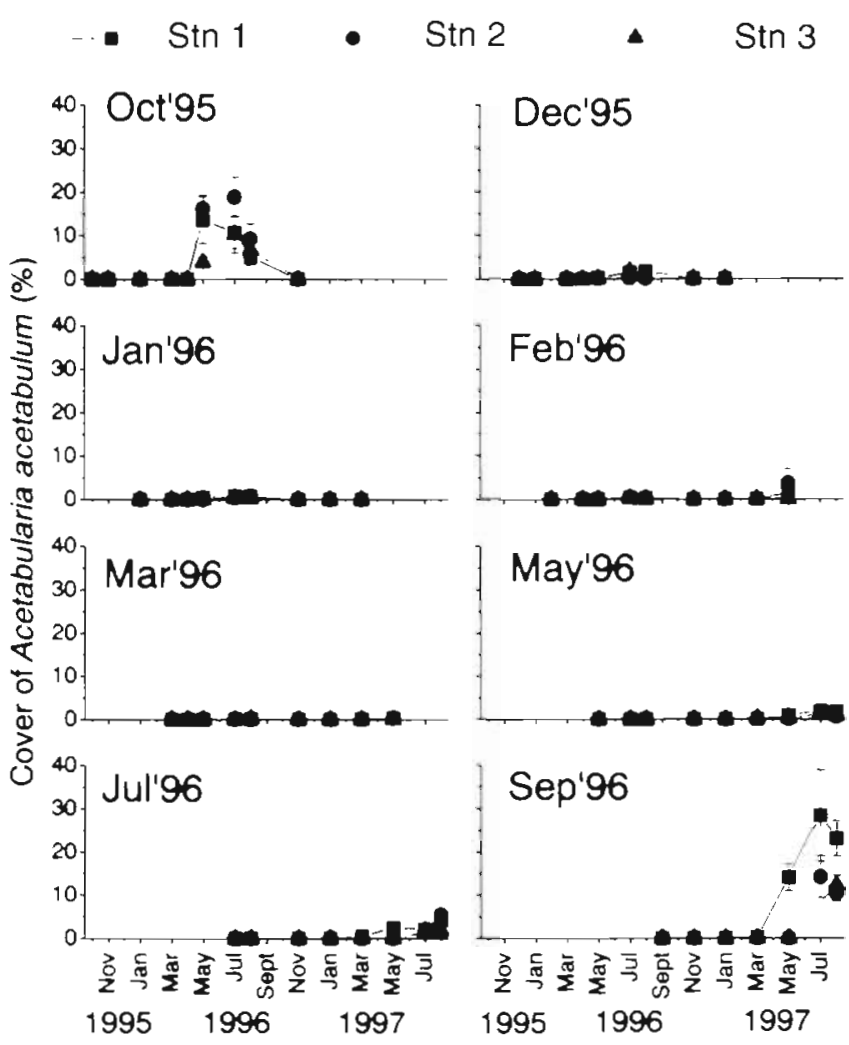

Fig. 8. Cover of Acetabularia acetabulum in patches of bare rock cleared at 8 difterent times (October 1995 to September 1996) and at 3 different stations (Stns 1 to 3). Data are mean percentage covers $( \pm \mathrm{SE}, \mathrm{n}=9$ ) over 1 yr since patches were cleared. Data are pooled across 3 sites within each station

ever, were not consistent across experiments done in different years. Moreover, rates of colonisation of species varied in proximate locations on the shore and, in a previous experiment, were affected by the size of the patch and by the amount of sediment deposition (Airoldi 1998). Given this spatial and temporal variability, predicting quantitative differences in the abundance of erect algae among patches disturbed at different times and locations is probably difficult. Nevertheless, results from this and previous experiments and from observations gathered during several years in this area (Airoldi et al. 1995, Airoldi \& Cinelli 1997, Airoldi 1998) suggest that patches cleared in late autumn and winter consistently support less erect algae than patches cleared at any other time of the year. At depths where this study was done, herbivores are scarce (Airoldi 2000), and severe disturbance, which opens patches of bare rock, occurs primarily in late autumn and winter from storms and scouring by sediments (Airoldi et al. 1996, Airoldi \& Virgilio 1998). This regime of disturbance, unfavorable to recruitment of some erect algae, might be responsible for their low abundance in the study area. 
Temporally variable recruitment of algae is often attributed to temporal differences in the availability of propagules in the water column, which is related to the timing of reproduction (Sousa 1984b, Reed et al. 1988, Benedetti-Cecchi \& Cinelli 1994, Kendrick \& Walker 1994, Kim \& DeWreede 1996, but see Ang 1991). Contrary to other species that are not reproductive during the winter, crusts were reproductive throughout the year, as also observed in other studies (Adey \& Vassar 1975, Dethier 1981, Davis \& Wilce 1987, Kaehler \& Williams 1997). Early rates of recruitment of crusts, however, were significantly lower during winter and were spatially very variable. These differences were not related to the fertility of within-site adult conspecifics at the time when patches were cleared, suggesting that spatial and temporal differences in recruitment of crusts were probably influenced by factors other than the potential production of propagules. These factors might include hydrodynamic or other environmental factors affecting the dispersal, settlement, germination rate or survival of propagules. Recruitment of some algae may be negatively affected by sediment deposition and scour (Devinny \& Volse 1978, Reed et al. 1988, Kendrick 1991, Umar et al. 1998), which in the study area are intense during autumn and winter and are spatially variable (Airoldi \& Virgilio 1998). Previous experiments on this assemblage (Airoldi \& Cinelli 1997, Airoldi 1998), involving manipulation of rates of sediment deposition, suggested that early recruitment of crusts was negatively influenced by the presence of sediments (Airoldi unpubl. data). Rapid cover by turf, however, made it difficult to quantify the importance of this process over adequately long times, and further studies are necessary to test the hypothesis that low recruitment of crusts observed during the winter might have been related to high disturbance by sediments.

Regardless of variation in rates of recruitment, crusts were able to colonise patches cleared at all times of the year and at all locations. Crusts were always among the first colonisers of bare rock (see also Adey \& Vassar 1975, Dethier 1981, Kendrick 1991, Figueiredo 1997), thus colonising primary space before lateral invasion by turf. Specific long-term experiments on the ecology of crusts have shown that, in contrast to erect algae, crusts were able to grow and colonize additional space even after they became covered by turf (Airoldi 2000). The ability to continuously colonise available space, and the high tolerance for overgrowth by turf over a long time have been identified as the major determinants of the quantitative success of crusts in this assemblage (Airoldi 2000).

Temporal and spatial variability of disturbance had little effect on colonisation by turf, which quickly regained spatial dominance in all clearings by lateral vegetative encroachment and regrowth of surviving prostrate axes. Recovery was most fast in patches cleared in December 1995 and January 1996 and significantly differed among sites, but differences observed were, quantitatively, small. Similarly, in previous experiments, cover of turf was little affected by variable sizes of disturbance and by different levels of sediment deposition (Airoldi 1998, Airoldi \& Virgilio 1998). These results suggest that spatially and temporally variable disturbance has less effect on algae that recover by vegetative propagation than on algae that recruit by sexual propagules (see also Kendrick \& Walker 1994, Kim \& DeWreede 1996). These different responses to disturbance may depend on the fact that vegetative propagating thalli appear to be less vulnerable to a variety of physical and biological factors (e.g. wave action, sediment stress, bottom instability, herbivory, competition) than are sexual propagules (Hansen 1977, Sousa 1980, Sousa et al. 1981, D'Antonio 1986, Davis \& Wilce 1987, McCook \& Chapman 1992, Airoldi 1998). Thus vegetative propagation should be an important mechanism of recovery after most common disturbances (Davis \& Wilce 1987. Airoldi 1998), especially when damage to algae is patchy (Sousa 1980, McCook \& Chapman 1997) .

Results show that while recruitment by sexual propagules can be highly variable through space and time, recovery by vegetative propagation can be constant and predictable over a range of environmental conditions. This lack of variability can have important consequences on successional processes and on the dynamics of algal assemblages. Current models of community structure and dynamics emphasise the role of variability in rates and timing of recruitment (Connell 1985, Gaines \& Roughgarden 1985, Underwood \& Fairweather 1989, Sutherland 1990). The present study, conversely, reinforces the increasing evidence that the ability to rapidly and continuously recover by vegetative reproduction can be a major determinant of persistent spatial dominance in a variety of marine habitats (Karlson 1978, Lubchenco \& Menge 1978, Sousa et al. 1981, D'Antonio 1986, Vadas et al. 1990, McCook \& Chapman 1992, Airoldi 1998), which is consistent with more extensive observations on terrestrial assemblages (van Groenendael et al. 1997 and references therein). It appears thus important that future research focuses on factors affecting the ability of marine species to propagate vegetatively, and on the potential role of this life-history trait in influencing responses of assemblages to disturbances.

Acknowledgements. I wish to thank M. Abbiati, G. A Williams and his students and 4 anonymous referees for important comments on the manuscript. I am grateful to F. Lenzi and A. Vannucci for assistance with the field work. F. 
Lenzi also helped with slide scoring and graph preparation. Prof. Cinelli and Prof. Ceccherelli provided space and facilities at the Dipartimento di Scienze dell'Uomo e dell'Ambiente of the Università di Pisa and at the Laboratorio di Ecologia Sperimentale of the Università di Bologna in Ravenna, respectively. This work was supported by a post-doctoral grant of the Università di Pisa to L.A.

\section{LITERATURE CITED}

Abrahamson WG (1980) Demography and vegetative reproduction. In: Solbrig OT (ed) Demography and the evolution of plant populations. Blackwell Scientific, Oxford, p $89-106$

Adey WH, Vassar JM (1975) Colonization, succession and growth rates of tropical crustose coralline algae (Rhodophyta, Cryptonemiales). Phycologia 14:55-69

Airoldi L (1998) Roles of disturbance, sediment stress and substratum retention on spatial dominance in algal turf. Ecology 79:2759-2770

Airoldi L (2000) Effects of disturbance, life-history and overgrowth on coexistence of algal crusts and turfs. Ecology 8: $798-814$

Airoldi L, Cinelli F (1997) Effects of sedimentation on subtidal macroalgal assemblages: an experimental study from a Mediterranean rocky shore. J Exp Mar Biol Ecol 215: $269-288$

Airoldi L, Virgilio M (1998) Responses of turf-forming algae to spatial variations in the deposition of sediments. Mar Ecol Prog Ser 165:271-282

Airoldi L, Rindi F, Cinelli F (1995) Structure, seasonal dynamics and reproductive phenology of a filamentous turf assemblage on a sediment influenced, rocky subtidal shore. Bot Mar 38:227-237

Airoldi L, Fabiano M, Cinelli F (1996) Sediment deposition and movement over a turf assemblage in a shallow rocky coastal area of the Ligurian Sea. Mar Ecol Prog Ser 133:241-251

Ang PO (1991) Natural dynamics of a Fucus distichus (Phaeophyceae, Fucales) population: reproduction and recruitment. Mar Ecol Prog Ser 78:71-85

Benedetti-Cecchi L, Cinelli F (1994) Recovery of patches in an assemblage of geniculate coralline algae: variability at different successional stages. Mar Ecol Prog Ser 110: $9-18$

Bonotto S (1994) Developmental biology of Acetabularia. J Mar Biol Assoc UK 74:93-106

Booth DJ, Brosnan DM (1995) The role of recruitment dynamics in rocky shore and coral reef communities. In: Begon M. Fitter AH (eds) Advances in ecological research. Academic Press, San Diego, p 309-385

Breitburg DL (1985) Development of a subtidal epibenthic community: factors affecting species composition and the mechanisms of succession. Oecologia 65:173-184

Breitburg DL (1992) Episodic hypoxia in Chesapeake Bay: interacting effects of recruitment, behavior, and physical disturbance. Ecol Monogr 62:525-546

Connell JH (1985) The consequences of variation in initial settlement vs. post settlement mortality in rocky intertidal communities. J Exp Mar Biol Ecol 93: 11-45

Connell JH, Slatyer RO (1977) Mechanisms of succession in natural communities and their role in community stability and organization. Am Nat 111:1119-1144

D'Antonio CM (1986) Role of sand in the domination of hard substrata by the intertidal alga Rhodomela larix. Mar Ecol Prog Ser 27:263-275
Davis AN, Wilce RT (1987) Floristic, phenology, and ecology of the sublitoral marine algae in an unstable cobble habitat (Plum Cove, Cape Ann, Massachusetts, USA). Phycologia $26: 23-34$

Day RW, Quinn GP (1989) Comparisons of treatments after an analysis of variance in ecology. Ecol Monogr 59:433-463

Dayton PK (1971) Competition, disturbance, and community organization: the provision and subsequent utilization of space in a rocky intertidal community. Ecol Monogr $45: 137-159$

Dayton PK, Tegner MJ, Parnell PE, Edwards PB (1992) Temporal and spatial patterns of disturbance and recovery in a kelp forest community. Ecol Monogr 62:421-445

Dethier MN (1981) Heteromorphic algal life histories: the seasonal pattern and response to herbivory of the brown crust, Ralfsia californica. Oecologia 49:333-339

Devinny JS, Volse LA (1978) The effect of sediments on the development of Macrocystis pyrifera gametophytes. Mar Biol 48:343-348

Dye AH (1993) Recolonization of intertidal macroalgae in relation to gap size and molluscan herbivory on a rocky shore on the east coast of southern Africa. Mar Ecol Prog Ser 95:263-271

Farrell TM (1989) Succession in a rocky intertidal community: the importance of disturbance size and position within a disturbed patch. J Exp Mar Biol Ecol 128:57-73

Figueiredo MAdeO (1997) Colonization and growth of crustose coralline algae in Abrolhos, Brazil. Proc 8th Int Coral Reef Symp 1:689-694

Foster MS (1975) Algal succession in a Macrocystis pyrifera forest. Mar Biol 32:313-329

Gaines SD, Roughgarden J (1985) Larval settlement rate: a leading determinant of structure in ecological communities of the marine intertidal zone. Proc Natl Acad Sci USA. 82:3707-3711

Hansen JE (1977) Ecology and natural history of Iridaea cordata (Gigartinales, Rhodophyta) growth. J Phycol 13: $395-402$

Hawkins SJ (1981) The influence of season and barnacles on the algal colonization of Patella vulgata exclusion areas. J Mar Biol Assoc UK 61:1-15

Hawkins SJ, Hartnoll RG (1983) Grazing of intertidal algae by marine invertebrates. Oceanogr Mar Biol Annu Rev 21: $195-282$

Kaehler S, Williams GA (1997) Do factors influencing recruitment ultimately influence the distribution and abundance of encrusting algae on seasonal tropical shores? Mar Ecol Prog Ser 156:87-96

Karlson R (1978) Predation and space utilization patterns in a marine epifaunal community. J Exp Mar Biol Ecol 31: $225-239$

Kendrick GA (1991) Recruitment of coralline crusts and filamentous turf algae in the Galapagos archipelago: effects of simulated scour, erosion and accretion. J Exp Mar Biol Ecol 147:47-63

Kendrick GA, Walker DI (1994) Role of recruitment in structuring beds of Sargassum spp. (Phaeophiyta) at Rottnest Island, Western Australia. J Phycol 30:200-208

Kennelly SJ (1987) Physical disturbances in an Australian kelp community. I. Temporal effects. Mar Ecol Prog Ser 40:145-153

Keough MJ (1984) Effects of patch size on the abundance of sessile marine inverterbrates. Ecology 1984:423-437

Keough MJ, Quinn GP (1998) Effects of periodic disturbances from trampling on rocky intertidal algal beds. Ecol Appl 8:141-161

Kim JH, DeWreede RE (1996) Effects of size and season of dis- 
turbance on algal patch recovery in a rocky intertidal community. Mar Ecol Prog Ser 133:217-228

Littler MM, Littler DS (1985) Nondestructive sampling. In: Littler MM, Littler DS (eds) Handbook of phycological methods. Ecological field methods: macroalgae. Cambridge University Press, Cambridge, p 161-175

Littler MM, Martz DR, Littler DS (1983) Effects of recurrent sand deposition on rocky intertidal organisms: importance of substrate heterogeneity in a fluctuating environment. Mar Ecol Prog Ser 11:129 -139

Lubchenco J, Menge BA (1978) Community development and persistence in a low rocky intertidal zone. Ecol Monogr $59: 67-94$

McCook LJ (1994) Understanding ecological community succession: causal models and theories, a review. Vegetatio 110:115-147

McCook LJ, Chapman ARO (1992) Vegetative regeneration of Fucus rockweed canopy as a mechanism of secondary succession on an exposed rocky shore. Bot Mar 35:35-46

McCook LJ, Chapman ARO (1997) Patterns and variations in natural succession following massive ice-scour of a rocky intertidal seashore. J Exp Mar Biol Ecol 214:121-147

Menge BA, Farrell TM, Olson AM, van Tamelen P, Turner T (1993) Algal recruitment and the maintenance of a plant mosaic in the low intertidal region of the Oregon coast. J Exp Mar Biol Ecol 170:91-116

Paine RT, Levin SA (1981) Intertidal landscapes: disturbance and the dynamics of pattern. Ecol Monogr 51:145-178

Palumbi SR, Jackson JBC (1982) Ecology of cryptic coral reef communities. II. Recovery from small disturbance events by encrusting bryozoa: the influence of 'host' species and lesion size. J Exp Mar Biol Ecol 64:103-115

Pickett STA, White PS (eds) (1985) The ecology of natural disturbance and patch dynamics. Academic Press, London

Reed DC (1990) The effects of variable settlement and early competition on patterns of kelp recruitment. Ecology $71: 776-787$

Reed DC, Laur DR, Ebeling AW (1988) Variation in algal dispersal and recruitment: the importance of episodic events. Ecol Monogr 58:321-335

Rindi F, Guiry MA, Cinelli F (1999) Morphology and reproduction of the adventive Mediterranean Rhodophyte Polysiphonia setacea. Hydrobiologia 398/399:91-100

Santelices B (1990) Patterns of reproduction, dispersal and recruitment in seaweeds. Oceanogr Mar Biol Annu Rev 28:177-276

Shumway SW, Bertness MD (1994) Patch size effects on

Editorial responsibility: Otto Kinne (Editor),

Oldendorf/Luhe, Germany marsh plant secondary succession mechanisms. Ecology $75: 564-568$

Sousa WP (1979) Experimental investigations of disturbance and ecological succession in a rocky intertidal algal community. Ecol Monogr 49:227-254

Sousa WP (1980) The responses of a community to disturbance: the importance of successional age and species' life histories. Oecologia 45:72-81

Sousa WP (1984a) The role of disturbance in natural communities. Annu Rev Ecol Syst 15:353-391

Sousa WP (1984b) Intertidal mosaics: patch size, propagule availability, and spatially variable patterns of succession. Ecology 65:1918-1935

Sousa WP, Schroeter SC, Gaines SD (1981) Latitudinal variation in intertidal community structure: the influence of grazing and vegetative propagation. Oecologia 48: $297-307$

Sutherland JP (1990) Recruitment regulates demographic variation in a tropical intertidal barnacle: Tetraclita panamensis (Pilsbry) on the Pacific coast of Costa Rica. J Exp Mar Biol Ecol 113:267-282

Turner T (1983) Complexity of early and middle successional stages in a rocky intertidal surfgrass community. Oecologia 60:56-65

Umar MJ, McCook LJ, Price IR (1998) Effects of sediment deposition on the seaweed Sargassum on a fringing coral reef. Coral Reefs 17:169-177

Underwood AJ, Fairweather PG (1989) Supply-side ecology and benthic marine assemblages. Trends Ecol Evol 4: $16-20$

Vadas RL, Wright WA, Miller SL (1990) Recruitment of Ascophyllum nodosum: wave action as a source of mortality. Mar Ecol Prog Ser 61:263-272

van den Hoek C, Mann DG, Jahns HM (1995) Algae: an introduction to phycology. Cambridge University Press, Cambridge

van Groenendael JM, Klimeš L, Klimešová J, Hedriks RJJ (1997) Comparative ecology of clonal plants. In: Silvertown J, Franco M, Harper JL (eds) Plant life histories. Cambridge University Press, Cambridge, p 191-209

Williams GA (1994) The relationship between shade and molluscan grazing in structuring communities on a moderately-exposed tropical rocky shore. J Exp Mar Biol Ecol 178:79-95

Witman JD (1987) Subtidal coexistence: storms, grazing, mutualism, and the zonation of kelps and mussels. Ecol Monogr 57:167-187

Submitted: July 26, 1999; Accepted: October 18, 1999 Proofs received from author(s): March 6, 2000 